\title{
Have plants evolved to self-immolate?
}

\section{David M. J. S. Bowman, Ben J. French and Lynda D. Prior*}

School of Biological Sciences, University of Tasmania, Hobart, TAS, Australia

Edited by:

Victoria Anne Hudspith, University

of Exeter, UK

Reviewed by:

Vicky Martine Temperton,

Forschungszentrum Jülich, Germany

Jeremy Midgley, University of Cape

Town, South Africa

*Correspondence:

Lynda D. Prior, School of Biological Sciences, University of Tasmania,

Private Bag 55, Hobart, Tasmania

7001, TAS, Australia

e-mail:lynda.prior@utas.edu.au
By definition fire prone ecosystems have highly combustible plants, leading to the hypothesis, first formally stated by Mutch in 1970, that community flammability is the product of natural selection of flammable traits. However, proving the "Mutch hypothesis" has presented an enormous challenge for fire ecologists given the difficulty in establishing cause and effect between landscape fire and flammable plant traits. Individual plant traits (such as leaf moisture content, retention of dead branches and foliage, oil rich foliage) are known to affect the flammability of plants but there is no evidence these characters evolved specifically to self-immolate, although some of these traits may have been secondarily modified to increase the propensity to burn. Demonstrating individual benefits from self-immolation is extraordinarily difficult, given the intersection of the physical environmental factors that control landscape fire (fuel production, dryness and ignitions) with community flammability properties that emerge from numerous traits of multiple species (canopy cover and litter bed bulk density). It is more parsimonious to conclude plants have evolved mechanisms to tolerate, but not promote, landscape fire.

\footnotetext{
Keywords: biomass burning, evolution, fire regime, landscape fire, niche construction, plant regeneration, plant traits
}

\section{INTRODUCTION}

The combination of carbon rich biomass, atmospheric oxygen, and ignitions makes landscape fire inevitable on Earth (Bowman et al., 2009). However, the occurrence, spread, and energy released by landscape fires is controlled by the physical environment. The most prominent environmental factor is climate because it influences the production of biomass, fuel arrangement across landscapes and its dryness, as well as providing lightning ignitions (Bradstock et al., 2012). The only life-forms that make fire are humans, and we, like our antecedents, are powerful agents in influencing the occurrence and spread of fires, given our capacities to modify fuels, provide ignitions and suppress fires (Bowman et al., 2011; Archibald et al., 2012). To what degree plant life has influenced the occurrence, extent and intensity of landscape fire remains controversial (Bradshaw et al., 2011a,b; Keeley et al., 2011b). Mutch (1970) hypothesized that "fire dependent plant communities burn more readily than non-fire dependent communities because natural selection has favored characteristics that make them more flammable" (Table 1). The "Mutch hypothesis" has logical appeal and is intellectually consequential for fire ecology and pyrogeography because it provides these disciplines with an evolutionary platform. However, because landscape fires affect entire plant communities rather than being restricted to individuals with heritable flammable characteristics, it is difficult to avoid group selection arguments (Snyder, 1984; Troumbis and Trabaud, 1989; Bond and Midgley, 1995; Scarff and Westoby, 2006).

A number of theoretical models have attempted to reconcile the evolution of flammability with individualistic selection theory by proposing ways that self-immolation can increase individual fitness or advantage to their offspring (Bond and Midgley,
1995; Kerr et al., 1999; Gagnon et al., 2010). For instance, Bond and Midgley (1995) developed a "kill thy neighbor" model, which demonstrated that a trait promoting canopy flammability amongst a population of closely spaced conspecific individuals could increase reproductive fitness on the condition it also conferred other evolutionary advantages. Recently, Midgley (2013) has withdrawn his support for this model because of unrealistic assumptions, such as the need for the seed shadow of the flammable individual to closely align with the fire footprint, and for its seedlings that inherit the flammable trait to be more competitive in post-fire environments. Likewise, Midgley (2013) argues that the "pyrogenicity as protection" hypothesis (Gagnon et al., 2010), which posits that flammable crowns are protective of soil seed banks and subterranean bud banks, shares similar flaws to the Bond and Midgley (1995) model.

A feature of the discussion about the evolution of flammability is that flammability traits have been conflated with strategies that enable plants to recover following fire, such as resprouting from basal or aerial bud banks, and storing seeds in aerial or soil seed banks (Saura-Mas et al., 2010; Clarke et al., 2013). Such strategies manifestly increase the fitness of individual plants in fire prone landscapes. Traits that unambiguously assist post-fire recovery and regeneration can be used in ancestral trait reconstructions, illuminating evolutionary processes within clades. Examples include fire-cued flowering (Bytebier et al., 2011), the epicormic strands that allow eucalypts to resprout after fire (Crisp et al., 2011), and xylopodia and thick corky bark in South American savanna species (Simon et al., 2009) (Table 1). In contrast, traits that purportedly increase flammability are not so obviously related to the fitness of individuals. Some authors have 
Table 1 | Summary of hypotheses regarding evolution of flammable traits in plants, and possible examples.

\begin{tabular}{|c|c|c|c|c|}
\hline Syndrome & Ancestral state & Evolved state & Example & References \\
\hline Mutch & Recovery/tolerance of fire & High flammability & Eucalyptus & Crisp et al., 2011 \\
\hline Mutch's converse & High flammability & Recovery/tolerance of fire & $\begin{array}{l}\text { Serotiny and thick bark in Pinus } \\
\text { Thick bark, xylopodia in savanna plants } \\
\text { Fire-cued flowering in orchids }\end{array}$ & $\begin{array}{l}\text { He et al., } 2012 \\
\text { Simon et al., } 2009 \\
\text { Bytebier et al., } 2011\end{array}$ \\
\hline Midgley's alternative & High flammability & Low flammability & Branch shedding in Pinus & He et al., 2012 \\
\hline
\end{tabular}

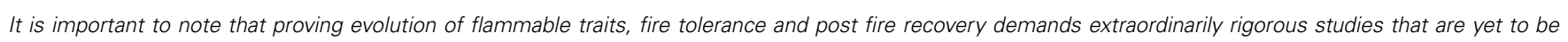
achieved (Bradshaw et al., 2011a,b; Keeley et al., 2011b). We call this stricture "Bradshaw's null."

rejected the notion that plants have evolved any traits to be flammable, indeed questioning the entire basis of the plant -fire evolutionary nexus (Bradshaw et al., 2011a). This leads to the basic question that is the subject of this review: "what plant traits and community attributes are known to increase flammability and could have arisen from natural selection through an evolutionary fire-feedback loop?" For the purposes of this review we define flammability as the propensity of living or dead plant material to ignite and sustain combustion.

\section{FLAMMABILITY TRAITS BIOMASS WATER CONTENT}

Water in plant tissue is a heat sink, increasing the amount of energy required for fuels to ignite and sustain combustion. Therefore moisture content of living and dead fuels is the most fundamental constraint on biomass flammability (Gill and Moore, 1996; Alessio et al., 2008b; De Lillis et al., 2009; Alexander and Cruz, 2013; Murray et al., 2013) (Table 2). Leaf moisture content strongly affects flammability and is highly variable amongst life forms and biomes, exceeding 95\% in succulents (Lamont and Lamont, 2000) and being as low as $20 \%$ in some sclerophyllous species (De Lillis et al., 2009). Although drought tolerating plants typically have more combustible living and dead foliage than mesic species, this correlation largely reflects the effect of the environment rather than inherent features that have evolved to increase flammability (Dickinson and Kirkpatrick, 1985; Berry et al., 2011; Hoffmann et al., 2012; Davies and Nafus, 2013; Seo and Choung, 2014). This point is exemplified by otherwise non-flammable rain forest foliage and litter beds burning under extreme drought conditions (Cochrane and Laurance, 2008) (Figure 1A).

\section{ORGANIC CHEMISTRY}

Foliar organic chemistry has a secondary effect on flammability after LMC (Alessio et al., 2008a,b; De Lillis et al., 2009; Page et al., 2012) (Table 2). For example, volatile organic compounds (VOCs such as terpenes and phenolics) can reduce ignition temperatures of living and dead leaves (Owens et al., 1998; Ormeno et al., 2009). However, VOCs also play an important role in herbivore defense (Owens et al., 1998; Page et al., 2012; Loreto et al., 2014), confounding their attribution as flammability adaptations (Dickinson and Kirkpatrick, 1985; Kerr et al., 1999; Schwilk and Kerr, 2002; Holmes, 2009). For example, variation in leaf terpenes of eucalypts, a notoriously flammable group of plants, is known to serve a wide variety of functions including influencing insect and mammalian herbivory and attracting insect pollinators, and has knock-on effects on decomposition and nutrient cycling (Keszei et al., 2008). Indeed, there is evidence of co-evolution between the diversification of plant secondary compounds and the intensity of special mammalian herbivores on eucalypt foliage (Moore et al., 2005) (Figure 1B).

\section{INORGANIC CHEMISTRY}

Leaves of flammable sclerophylls, which typically occur on infertile soils, have high foliar silica contents and low concentrations of other nutrients, especially phosphorus and nitrogen, compared to non-sclerophyll leaves (Turner, 1994). However, sclerophyllous foliage is imperfectly correlated with fire adapted vegetation (Midgley, 2013). The maquis shrublands of New Caledonia, for example, are dominated by sclerophyllous species, of which only about 19\% persist through fires (McCoy et al., 1999) (Figure 1C), despite close phylogenetic links to fire-tolerant Australian heathland species. In principle, high phosphate concentrations in foliage could inhibit combustion given that phosphate is commonly used in fire retardants, yet little support has been found for this hypothesis (Scarff and Westoby, 2006; Scarff et al., 2012).

\section{LEAF DIMENSIONS}

Leaf dimensions (size, thickness, and shape) influence the flammability of individual leaves. Thinner leaves, which have a high surface area to volume ratio and high specific leaf area, and larger leaves, appear to be more ignitable (Gill and Moore, 1996; Saura-Mas et al., 2010; Murray et al., 2013). However, species with small leaves tend to have narrow, frequently branched twigs and dense wood, which burn more intensely (Westoby and Wright, 2003; Pickup et al., 2005), potentially counteracting the lower flammability of small individual leaves. While flammability of live individual leaves may influence the spread of crown fires, surface fires are more strongly influenced by the flammability of litter beds. Large, long leaves may produce more flammable litter fuels because of lower packing density, which influences oxygen availability (Scarff and Westoby, 2006; Belcher et al., 2010; De Magalhães and Schwilk, 2012). For instance, an American study has found a link between abundance in litter fuels of Pinus species, which have long needle-shaped leaves, and fire severity (Schwilk and Caprio, 2011). Importantly, individual species have nonadditive effects on litter flammability, which tends to be driven by the most flammable leaves in the litter (De Magalhães and Schwilk, 2012; Van Altena et al., 2012). 




\section{FIGURE 1 | Diverse plant traits that affect vegetation flammability.}

(A) Surface fire in Amazonian rainforest leaf litter and ground cover vegetation during a severe drought, when leaf moisture context of living and dead foliage was very low (Photo: Mark Cochrane); (B) Koala (Phascolarctos cinereus), an iconic specialist mammalian herbivore involved in a co-evolutionary relationship with eucalypt leaf secondary chemical defenses. These defenses also make foliage exceptionally flammable (Photo Kath Handasyde); (C) New Caledonian maquis vegetation, which is dominated by sclerophyll species with phylogenetic links to Australian flammable heathland, yet has a poor capacity to recover from fire (Photo David Bowman); (D) leaf retention of Richea pandanifolius, a fire sensitive Gondwana rainforest giant heath, demonstrates that this trait is not universally associated with increasing flammability (Photo David Bowman); (E) low bulk density annual grass layer in eucalypt savanna is exceptionally flammable (Photo Don Franklin); (F) post-flowering die-off of the giant bamboo Bambusa arnhemica in frequently burnt eucalypt savanna. The dead bamboo is much less flammable than the grass layer in surrounding savanna (photo Don Franklin); (G) decorticating bark on a SE Asian tropical rainforest tree Cratoxylum cochinchinense demonstrates that this trait is not necessarily related to spreading fires via fire brands (Photo David Tng); (H) abrupt rain forest boundary in north Queensland which limits the spread of savanna fires, as evidenced by the shrubs burnt in the preceding dry season (Photo David Bowman).

\section{Dead leaf retention}

When leaves die they are typically shed, although some plants retain dead leaves for extended periods; these dead leaves have low LMC relative to live foliage (Page et al., 2012). It has been suggested that dead leaf retention is an adaptation to promote plant flammability (He et al., 2011) and community flammability (Santana et al., 2011). He et al. (2011) used dated phylogenies to show that dead leaf retention in the Australian genus Banksia arose after the appearance of serotiny, suggesting that dead leaf retention could have evolved to increase the probability of fire and ensure that seeds are liberated. However, retention of dead foliage is not restricted to plants that occur in flammable environments: an example is the fire sensitive endemic Tasmanian rainforest arborescent monocot Richea pandanifolia (Figure 1D), signaling that this trait is not universally related to flammability. Indeed, it has been suggested that the retention of dead foliage in tall grasses is an adaptation to reduce the intensity of mammalian herbivory, but which may have also increased landscape fire activity (Mingo and Oesterheld, 2009; Antonelli et al., 2011).

\section{PHENOLOGY}

In seasonally dry environments, phenology influences flammability by causing seasonal patterns in production and senescence of both leaves (deciduous plants) and of whole plants (annuals) (Keeley and Bond, 1999; Elliott et al., 2009; Bajocco et al., 2010; Ripley et al., 2010; De Angelis et al., 2012; Davies and Nafus, 2013). Obvious examples are senescence of annual herbs and grasses, leading to increased community flammability in the nongrowing season because of high fine fuel loads (Wittich, 2011) (Figure 1E), as well as the dry season combustion of leaf litter in tropical dry forests (Mondal and Sukumar, 2014). This seasonal surge in available fuel has not been attributed to evolution, 
Table 2 | Summary of the evidence for the effects and evolutionary origin of potential flammability.

\begin{tabular}{|c|c|c|c|c|}
\hline Property & $\begin{array}{l}\text { Evidence of effect } \\
\text { on flammability }\end{array}$ & References & $\begin{array}{l}\text { Evidence of evolution } \\
\text { for flammability }\end{array}$ & References \\
\hline \multicolumn{5}{|l|}{ LEAF } \\
\hline Organic chemistry & Strong & $\begin{array}{l}\text { Dickinson and Kirkpatrick, 1985; White, 1994; Owens et al., } \\
\text { 1998; Kerr et al., 1999; Schwilk and Kerr, 2002; De Lillis et al., } \\
\text { 2009; Holmes, 2009; Ormeno et al., 2009; Page et al., 2012; } \\
\text { but see (Alessio et al., 2008a,b) }\end{array}$ & No & \\
\hline Inorganic chemistry & Moderate & $\begin{array}{l}\text { Dickinson and Kirkpatrick, 1985; Scarff and Westoby, 2006; } \\
\text { Scarff et al., } 2012\end{array}$ & No & \\
\hline Leaf dimensions & Moderate & $\begin{array}{l}\text { Direct effect (Gill and Moore, 1996; Murray et al., 2013) and } \\
\text { indirect effect through litter bed structure (Scarff and } \\
\text { Westoby, 2006; Schwilk and Caprio, 2011; De Magalhães and } \\
\text { Schwilk, 2012; Engber and Varner III, 2012) }\end{array}$ & No & \\
\hline Leaf retention & Moderate & He et al., 2011; Santana et al., 2011 & Equivocal & He et al., 2011 \\
\hline Decorticating bark & Moderate & Ganteaume et al., 2009; Koo et al., 2010; Ellis, 2011 & No & \\
\hline Branch retention & Strong & $\begin{array}{l}\text { Schwilk and Ackerly, 2001; Schwilk, 2003; Ne'eman et al., } \\
\text { 2004; Keeley, 2012; Seo and Choung, } 2014\end{array}$ & Equivocal & He et al., 2012 \\
\hline Plant architecture & Moderate & $\begin{array}{l}\text { Archibald and Bond, 2003; Schwilk, 2003; Mitsopoulos and } \\
\text { Dimitrakopoulos, 2007; Hoffmann et al., 2012; Ledig et al., } \\
2013\end{array}$ & No & \\
\hline \multicolumn{5}{|l|}{ COMMUNITY } \\
\hline Fuel moisture & Strong & $\begin{array}{l}\text { Dickinson and Kirkpatrick, 1985; Bowman and Wilson, 1988; } \\
\text { Rollins et al., 2002; Ray et al., 2005; Jolly, 2007; Hoffmann } \\
\text { et al., 2012; Alexander and Cruz, 2013; Davies and Nafus, } \\
2013\end{array}$ & No & \\
\hline Canopy cover & Strong & $\begin{array}{l}\text { Ray et al., 2005; Peterson and Reich, 2008; Warman and } \\
\text { Moles, 2009; Hoffmann et al., 2012; Little et al., 2012; } \\
\text { Murphy and Bowman, 2012; Trauernicht et al., } 2012\end{array}$ & No & \\
\hline
\end{tabular}

Evidence for an effect on flammability is a necessary but not sufficient condition for demonstrating selection for flammability.

although Keeley and Bond (1999) hypothesized that synchronized mass flowering and die-off of bamboos is an evolutionary strategy to generate a "synchronous fuel load that significantly increases the potential for wildfire disturbance." However, there is little evidence that fire is a key feature in the evolution of bamboo lifehistory (Saha and Howe, 2001). Franklin and Bowman (2003) found no support for this hypothesis from the north Australian giant bamboo, Bambusa arnhemica, which grows in an environment where fire is extremely frequent. The seedlings of this species did not require fire to establish, and dead adult biomass had low flammability (Franklin and Bowman, 2003) (Figure 1F).

\section{DECORTICATING BARK}

Lofted pieces of burning fuel (termed firebrands) can create spot fires ahead of a fire-front and are a key mechanism promoting fire spread (Koo et al., 2010). Decorticating eucalypt bark has been hypothesized to evolve to spread fires (Jackson, 1968; Mount, 1979). However, the individual fitness benefits of this trait are not obvious (Ellis, 1965). In any case decorticating bark also occurs in non-flammable environments (Figure 1G), and has been suggested as defending against epiphyte infestation (Carsten et al., 2002; Wyse and Burns, 2011). 


\section{SELF-PRUNING AND BRANCH RETENTION}

Shedding of dead lower branches reduces continuity between surface fuels and the canopy. Conversely, retained dead branches create fuel ladders and allow fires to reach the crown of individual trees and their neighbors (Schwilk, 2003; Keeley, 2012; Seo and Choung, 2014). Phylogenetic analysis shows that shedding of branches may have evolved in the genus Pinus to reduce crown fires (He et al., 2012), in contrast to the ancestral condition of branch retention that promotes crown fires. The latter is often associated with serotiny (Gauthier et al., 1996; Schwilk and Ackerly, 2001; Ne'eman et al., 2004), a derived trait that apparently offered an alternative strategy to deal with high fire activity during the Cretaceous (He et al., 2012).

\section{PLANT ARCHITECTURE AND CANOPY MORPHOLOGY}

Plant architecture may also influence flammability. For instance, frequent fire on the New Jersey Pine Plains has selectively maintained a dwarf, crooked form of Pinus rigida which is more flammable than the surrounding tall forest (Ledig et al., 2013). In some Mediterranean environments, plants with firedependent seeding strategy have open crowns with fine leaves that promote flammability (Saura-Mas et al., 2010), although this crown morphology also occurs in environments where fire is not central to plant regeneration, such as South American shrublands with similar climates (Keeley et al., 2011a). Shading by dense canopies of individual trees influences understory floristics and local microclimate (Peterson and Reich, 2008; Cohn et al., 2011), thereby affecting fire regime. For example, closed crowned trees can suppress grasses in savannas (Hoffmann et al., 2012) (Figure 1H).

\section{DISCUSSION}

Our review has not been able to identify any individual plant traits attributes that exclusively influence flammability (Table 1). Further, we show that plant traits that increase flammability may exist in plant communities that are rarely burnt, suggesting they have evolved independently of landscape fire. It is probable that some traits related to flammability, such as foliar chemistry, may be "exaptations" (Gould and Vrba, 1982)—-traits with another function that incidentally increases flammability (Trabaud, 1976; Snyder, 1984; Bradshaw et al., 2011a). Such micro-evolutionary processes are apparent in the selection of more flammable genotypes of Ulex parviflorus (Mediterranean gorse) (Pausas and Moreira, 2012; Moreira et al., 2014). The benefit of increased flammability for plants that require fire disturbance to regenerate is possibly greatest in environments where background fire frequency is low, for example in tall eucalypt forests compared to tropical eucalypt savannas (Bowman and Wilson, 1988; Murphy and Bowman, 2012). Increased flammability may also be of selective benefit for plants that recover following fire disturbance, thereby deflecting successional pathways from less flammable mature forests. For example, such a seral "niche construction" model has been proposed to explain the dynamics of eucalypt forests and rainforests in high rainfall areas of Australia (Jackson, 1968; Bowman, 2000). The eucalypt forests require fire to regenerate so that unless fire occurs within their life span the eucalypts are replaced by comparatively fire sensitive, continuously regenerating rainforest species (Tng et al., 2012). Clarke et al. (2014) tested this hypothesis and found that foliage and litter from eucalypt forest was not more flammable that from rainforest. Further, eucalypt forests regenerating after severe fire did not have more flammable litter compared to areas affected by less severe fire or long unburnt, so there was no evidence that fire selected for higher litter flammability. Likewise, Lindenmayer et al. (2011) have suggested that stands of Eucalyptus regnans regenerating following disturbance are inherently more flammable than long unburnt stands, yet a recent analysis shows this effect was not evident in stands burnt within the last 7 years, and was most pronounced in stands burnt around 15 years ago (Taylor et al., 2014), discounting the influence of shortlived herbaceous fire weeds that characterize the post-fire plant community (Jackson, 1968).

It is important to acknowledge that traits that influence plant combustion are not exclusively associated with flammability. This complicates macro-evolutionary ancestral state reconstructions by demanding joint consideration of the evolution of fire tolerating traits and recovery mechanisms with flammable traits. Mutch (1970) suggested that fire promoting traits followed the development of fire tolerating and recovery mechanisms, but it is possible that inherently flammable plants drove the evolution of plant recovery mechanisms - an evolutionary pathway known as "Mutch's converse" (Kerr et al., 1999; Schwilk and Ackerly, 2001; Schwilk and Kerr, 2002). The analysis of serotiny in Banksia, and self-pruning, bark thickness and serotiny in Pinus (e.g., He et al., 2011, 2012) suggest the latter, but many more ancestral trait reconstructions are required before generalizations can be drawn about the most typical evolutionary pathways, and how these patterns vary biogeographically. A confounding factor in such reconstruction is that plants that evolve traits to tolerate or recover from fire may be under less selection pressure to reduce their flammability, leading to positive correlations between flammability and fire tolerance without evolutionary selection for high flammability. Importantly, Midgley (2013) points out that selection for non-flammable traits, such as branch shedding, avoids many of the problems with the Mutch hypothesis, given the manifest individual fitness benefits of avoiding self-immolation. More research needs to be directed to this hypothesis, which we call "Midgley's alternative."

The focus on flammability traits of individuals in both theoretical models and ancestral trait reconstructions obscures the fact that wildfire propagates through vegetation made up of multiple species, so the most appropriate unit of analysis should be the plant community. Community flammability is controlled by the interplay of climate with vegetation canopy cover, fuel continuity and litter bed characteristics (Table 1). This is well illustrated by boundaries between vegetation types with sharply contrasting flammability, such as savanna and tropical rainforests: forests which have closed canopies result in microclimates characterized by higher humidity, lower wind velocities, cooler temperatures, reduced evaporation and hence reduced fire risk compared to open-canopied savannas (Bowman and Wilson, 1988; Ray et al., 2005; Hoffmann et al., 2012; Little et al., 2012; Veldman et al., 2013). Litter beds are an emergent property of the plant community because the mix of dead foliage with different sizes and 
shapes affects fuel bulk density, which in turn influences flammability (Scarff and Westoby, 2006; Kane et al., 2008; Schwilk and Caprio, 2011; De Magalhães and Schwilk, 2012; Engber and Varner III, 2012; Van Altena et al., 2012; Murray et al., 2013; McGlone et al., 2014) (Figure 1H). Large, thin leaves and leaves with complex shapes (such as compound leaves or leaves with lobed margins) result in well aerated litter beds that typically dry out quickly and readily combust during dry periods (Scarff and Westoby, 2006; Kane et al., 2008; Schwilk and Caprio, 2011; De Magalhães and Schwilk, 2012; Engber and Varner III, 2012). The most extreme examples of this effect are tall tropical grasses, which produce highly combustible fuel beds, in contrast to denser leaf litter fuels: the difference in these fuel types reinforces forestsavanna boundaries (Hoffmann et al., 2012) (Figure 1H).

The stark differences in flammability of grasses and broadleaved fuels also invites consideration of the flammability traits amongst Poaceae lineages. Some grass genera have high flammability due to massive accumulation of fine, well-aerated fuels (e.g., Andropogon) (Setterfield et al., 2010), "haying-off" after the growing season (e.g., annual Sorghum) (Elliott et al., 2009), retention of dead foliage, or resin-rich leaves [e.g., Triodia (Allan and Southgate, 2002)]. Indeed, globally, many C4 savanna grasslands are maintained by fire (Scott et al., 2014). However, some other grasses are less flammable than surrounding vegetation, for example dense swards of Australian alpine Poa compared to surrounding heathlands (Williams et al., 2006). While invasive grasses can drive a grass fire cycle (D'Antonio and Vitousek, 1992; Setterfield et al., 2010), it is important to note that in many situations this feedback loop is driven by high anthropogenic ignitions and an absence of co-evolved grazers. More investigation of the flammable traits of grasses, and their evolutionary pathways, including co-evolutionary relationships with grazers (e.g., Linder and Rudall, 2005; Antonelli et al., 2011; McGlone et al., 2014) are warranted.

Clarke et al. (2014) used a mosaic of flammable eucalypt forest and far less flammable rainforest as an evolutionary "model system" to show there were no differences in the flammability of foliage of congeners in these contrasting forest types. They also found no differences in the flammability of litter fuels dried to a standard moisture content. This led them to reject the Mutch hypothesis that individual plant flammability is under natural selection; rather, they concluded that community flammability differences were related to the contrasting microclimates under the open eucalypt and the dense rainforest canopies. It is important to note that low flammability rainforest can establish beneath canopies of mature eucalypt forests growing in moist environments, blunting the view that eucalypt canopy openness is a specific adaptation to increase flammability (Tng et al., 2012).

Keeley et al. (2011b) argue that the most profitable route to disclosing the evolutionary relationships between plants and landscape fire is to understand the nexus between fire regimes and plant traits. However, we suspect fire regimes are too fluid to provide a sufficiently strong evolutionary pressure to select for highly flammable traits. Fire regimes respond rapidly to changing patterns of ignitions, intensity and type of herbivory, new species of invasive plants and longer term climate changes. For example, the loss of Pleistocene megafauna in both North America (Gill et al., 2009) and Australia (Rule et al., 2012) appeared to change fire regimes due to the proliferation of woody biomass, which fuelled more intense fires. Likewise, invasive species can abruptly change flammability by altering vertical or horizontal fuel continuity, and hence facilitate the spread of fires into canopies or amongst otherwise spatially isolated plants. This is well illustrated by the invasion of dry rainforests in Queensland by the woody shrub Lantana camara, which changes fire type from surface litter fires to shrub canopy fires that can kill rainforest trees, or invasive Bromis tectorum, which changes horizontal fuel continuity, causing loss of succulents such as giant saguaro cacti (Carnegiea gigantea) (Thomas and Goodson, 1992). Such shifting patterns of fire activity filtering numerous plant traits from multiple species make it difficult to sustain the notion that numerous species in communities have all evolved to collectively self-immolate. It is more parsimonious to view fire activity as a powerful filter that sorts plants with pre-existing flammabilities and hones regeneration strategies.

\section{AUTHOR CONTRIBUTIONS}

David Bowman conceived the ideas for the manuscript, and Ben French carried out the initial literature review. All authors contributed to the writing.

\section{ACKNOWLEDGMENTS}

This research is an output from the Landscapes and Policy Research Hub. The hub is supported through funding from the Australian Government's National Environmental Research Programme. Sam Wood and Greg Jordan provided helpful discussion in developing this paper. We thank Mark Cochrane, Kath Handasyde, Don Franklin, and David Tng for providing us with photographs at short notice.

\section{REFERENCES}

Alessio, G. A., Penuelas, J., De Lillis, M., and Llusia, J. (2008a). Implications of foliar terpene content and hydration on leaf flammability of Quercus ilex and Pinus halepensis. Plant Biol. 10, 123-128. doi: 10.1111/j.1438-8677.2007.00011.x

Alessio, G. A., Penuelas, J., Llusia, J., Ogaya, R., Estiarte, M., and De Lillis, M. (2008b). Influence of water and terpenes on flammability in some dominant Mediterranean species. Int. J. Wildland Fire 17, 274-286. doi: 10.1071/ WF07038

Alexander, M. E., and Cruz, M. G. (2013). Assessing the effect of foliar moisture on the spread rate of crown fires. Int. J. Wildland Fire 22, 415-427. doi: 10.1071/WF12008

Allan, G. E., and Southgate, R. I. (2002). "Fire regimes in the spinifex landscapes of Australia," in Flammable Australia: the Fire Regimes and Biodiversity of a Continent, eds R. A. Bradstock, J. E. Williams, and A. M. Gill (Cambridge: Cambridge University Press), 145-176.

Antonelli, A., Humphreys, A. M., Lee, W. G., and Linder, H. P. (2011). Absence of mammals and the evolution of New Zealand grasses. Proc. R. Soc. 278, 695-701. doi: $10.1098 / \mathrm{rspb} .2010 .1145$

Archibald, S., and Bond, W. J. (2003). Growing tall vs growing wide: tree architecture and allometry of Acacia karroo in forest, savanna, and arid environments. Oikos 102, 3-14. doi: 10.1034/j.1600-0706.2003.12181.x

Archibald, S., Staver, A. C., and Levin, S. A. (2012). Evolution of humandriven fire regimes in Africa. Proc. Natl. Acad. Sci. U.S.A. 109, 847-852. doi: 10.1073/pnas.1118648109

Bajocco, S., Rosati, L., and Ricotta, C. (2010). Knowing fire incidence through fuel phenology: a remotely sensed approach. Ecol. Model. 221, 59-66. doi: 10.1016/j.ecolmodel.2008.12.024 
Belcher, C. M., Mander, L., Rein, G., Jervis, F. X., Haworth, M., Hesselbo, S. P., et al. (2010). Increased fire activity at the Triassic/Jurassic boundary in Greenland due to climate-driven floral change. Nat. Geosci. 3, 426-429. doi: 10.1038/ngeo871

Berry, Z. C., Wevill, K., and Curran, T. J. (2011). The invasive weed Lantana camara increases fire risk in dry rainforest by altering fuel beds. Weed Res. 51, 525-533. doi: 10.1111/j.1365-3180.2011.00869.x

Bond, W. J., and Midgley, J. J. (1995). Kill thy neighbor - an individualistic argument for the evolution of flammability. Oikos 73, 79-85. doi: $10.2307 / 3545728$

Bowman, D. M. J. S. (2000). Australian Rainforests: Islands of Green in a Land of Fire. Cambridge: Cambridge University Press.

Bowman, D. M. J. S., Balch, J., Artaxo, P., Bond, W. J., Cochrane, M. A., D’Antonio, C. M., et al. (2011). The human dimension of fire regimes on Earth. J. Biogeogr. 38, 2223-2236. doi: 10.1111/j.1365-2699.2011.02595.x

Bowman, D. M. J. S., Balch, J. K., Artaxo, P., Bond, W. J., Carlson, J. M., Cochrane, M. A., et al. (2009). Fire in the Earth System. Science 324, 481-484. doi: $10.1126 /$ science. 1163886

Bowman, D. M. J. S., and Wilson, B. A. (1988). Fuel characteristics of coastal monsoon forests, Northern Territory, Australia. J. Biogeogr. 15, 807-817. doi: $10.2307 / 2845341$

Bradshaw, S. D., Dixon, K. W., Hopper, S. D., Lambers, H., and Turner, S. R. (2011a). Little evidence for fire-adapted plant traits in Mediterranean climate regions. Trends Plant Sci. 16, 69-76. doi: 10.1016/j.tplants.2010. 10.007

Bradshaw, S. D., Dixon, K. W., Hopper, S. D., Lambers, H., and Turner, S. R. (2011b). Response to Keeley et al.: fire as an evolutionary pressure shaping plant traits. Trends Plant Sci. 16, 405-405. doi: 10.1016/j.tplants.2011.05.005

Bradstock, R. A., Cary, G. J., Davies, I., Lindenmayer, D. B., Price, O. F., and Williams, R. J. (2012). Wildfires, fuel treatment and risk mitigation in Australian eucalypt forests: insights from landscape-scale simulation. J. Environ. Manage. 105, 66-75. doi: 10.1016/j.jenvman.2012.03.050

Brooks, M. L., D’Antonio, C. M., Richardson, D. M., Grace, J. B., Keeley, J. E., Ditomaso, J. M., et al. (2004). Effects of invasive alien plants on fire regimes. Bioscience 54, 677-688. doi: 10.1641/0006-3568(2004)054[0677:EOIAPO]2. $0 . \mathrm{CO} ; 2$

Bytebier, B., Antonelli, A., Bellstedt, D. U., and Linder, H. P. (2011). Estimating the age of fire in the Cape flora of South Africa from an orchid phylogeny. Proc. $R$. Soc.278, 188-195. doi: 10.1098/rspb.2010.1035

Carsten, L. D., Juola, F. A., Male, T. D., and Cherry, S. (2002). Host associations of lianas in a south-east Queensland rain forest. J. Trop. Ecol. 18, 107-120. doi: $10.1017 /$ S0266467402002067

Castagneri, D., Esposito, A., Bovio, G., Mazzoleni, S., Seneca, U., Catalanotti, A., et al. (2013). Fuel vertical structure affects fire sustainability and behaviour of prescribed burning in Spartium junceum shrublands. Ann. For. Sci. 70, 863-871. doi: 10.1007/s13595-013-0327-3

Clarke, P. J., Lawes, M. J., and Midgley, J. J. (2013). Resprouting as a key functional trait in woody plants - challenges to developing new organizing principles. New Phytol. 197, 19-35. doi: 10.1111/nph.12001

Clarke, P. J., Prior, L. D., French, B. J., Vincent, B., Knox, K. J. E., and Bowman, D. J. M. S. (2014). Using a rainforest-flame forest mosaic to test the hypothesis that leaf and litter fuel flammability is under natural selection. Oecologia. doi: 10.1007/s00442-014-3071-y. [Epub ahead of print].

Cochrane, M. A., and Laurance, W. F. (2008). Synergisms among fire, land use, and climate change in the Amazon. Ambio 37, 522-527. doi: 10.1579/0044-744737.7.522

Cohn, J. S., Lunt, I. D., Ross, K. A., and Bradstock, R. A. (2011). How do slowgrowing, fire-sensitive conifers survive in flammable eucalypt woodlands? J. Veg. Sci. 22, 425-435. doi: 10.1111/j.1654-1103.2011.01280.x

Crisp, M. D., Burrows, G. E., Cook, L. G., Thornhill, A. H., and Bowman, D. M. J. S. (2011). Flammable biomes dominated by eucalypts originated at the Cretaceous-Palaeogene boundary. Nat. Commun. 2, 193. doi: $10.1038 /$ ncomms 1191

D'Antonio, C. M., and Vitousek, P. M. (1992). Biological invasions by exotic grasses, the grass/fire cycle, and global change. Ann. Rev. Ecol. Syst. 23, 63-87.

Davies, G. M., Legg, C. J., Smith, A. A., and Macdonald, A. J. (2009). Rate of spread of fires in Calluna vulgaris-dominated moorlands. J. Appl. Ecol. 46, 1054-1063. doi: 10.1111/j.1365-2664.2009.01681.x

Davies, K. W., and Nafus, A. M. (2013). Exotic annual grass invasion alters fuel amounts, continuity and moisture content. Int. J. Wildland Fire 22, 353-358. doi: $10.1071 / \mathrm{WF} 11161$
De Angelis, A., Bajocco, S., and Ricotta, C. (2012). Phenological variability drives the distribution of wildfires in Sardinia. Landscape Ecol. 27, 1535-1545. doi: 10.1007/s10980-012-9808-2

De Lillis, M., Bianco, P. M., and Loreto, F. (2009). The influence of leaf water content and isoprenoids on flammability of some Mediterranean woody species. Int. J. Wildland Fire 18, 203-212. doi: 10.1071/WF07075

De Magalhães, R. M. Q., and Schwilk, D. W. (2012). Leaf traits and litter flammability: evidence for non-additive mixture effects in a temperate forest. J. Ecol. 100, 1153-1163. doi: 10.1111/j.1365-2745.2012.01987.x

Dickinson, K. J. M., and Kirkpatrick, J. B. (1985). The flammability and energy content of some important plant species and fuel components in the forests of southeastern Tasmania. J. Biogeogr.12, 121-134. doi: 10.2307/ 2844836

Dimitrakopoulos, A. P., and Papaioannou, K. K. (2001). Flammability assessment of Mediterranean forest fuels. Fire Technol. 37, 143-152. doi: 10.1023/A:1011641601076

Elliott, L. P., Franklin, D. C., and Bowman, D. M. J. S. (2009). Frequency and season of fires varies with distance from settlement and grass composition in Eucalyptus miniata savannas of the Darwin region of northern Australia. Int. J. Wildland Fire 18, 61-70. doi: 10.1071/WF06158

Ellis, P. F. M. (2011). Fuelbed ignition potential and bark morphology explain the notoriety of the eucalypt messmate 'stringybark' for intense spotting. Int. J. Wildland Fire 20, 897-907. doi: 10.1071/WF10052

Ellis, R. C. (1965). Correspondence. Aust. Forestry 29, 56-57. doi: 10.1080/00049158.1965.10675380

Engber, E. A., and Varner, III, J. M. (2012). Patterns of flammability of the California oaks: the role of leaf traits. Can. J. For. Res. 42, 1965-1975. doi: $10.1139 / \mathrm{x} 2012-138$

Franklin, D. C., and Bowman, D. M. J. S. (2003). Bamboo, fire and flood: regeneration of Bambusa arnhemica (Bambuseae: Poaceae) after mass-flowering and die-off at contrasting sites in monsoonal northern Australia. Aust. J. Bot. 51, 529-542. doi: 10.1071/BT03014

Gagnon, P. R., Passmore, H. A., Platt, W. J., Myers, J. A., Paine, C. E. T., and Harms, K. E. (2010). Does pyrogenicity protect burning plants? Ecology 91, 3481-3486. doi: 10.1890/10-0291.1

Ganteaume, A., Lampin-Maillet, C., Guijarro, M., Hernando, C., Jappiot, M., Fonturbel, T., et al. (2009). Spot fires: fuel bed flammability and capability of firebrands to ignite fuel beds. Int. J. Wildland Fire 18, 951-969. doi: 10.1071/WF07111

Ganteaume, A., Marielle, J., Corinne, L. M., Thomas, C., and Laurent, B. (2011). Effects of vegetation type and fire regime on flammability of undisturbed litter in Southeastern France. For. Ecol. Manage. 261, 2223-2231. doi: 10.1016/j. foreco.2010.09.046

Gauthier, S., Bergeron, Y., and Simon, J. P. (1996). Effects of fire regime on the serotiny level of jack pine. J. Ecol. 84, 539-548. doi: 10.2307/2261476

Gill, A. M., and Moore, P. H. R. (1996). Ignitability of Leaves of Australian Plants. Canberra: CSIRO.

Gill, J. L., Williams, J. W., Jackson, S. T., Lininger, K. B., and Robinson, G. S. (2009). Pleistocene megafaunal collapse, novel plant communities, and enhanced fire regimes in North America. Science 326, 1100-1103. doi: 10.1126/science. 1179504

Gould, S. J., and Vrba, E. S. (1982). Exaptation- a missing term in the science of form. Paleobiology 8, 4-15.

He, T. H., Pausas, J. G., Belcher, C. M., Schwilk, D. W., and Lamont, B. B. (2012). Fire-adapted traits of Pinus arose in the fiery Cretaceous. New Phytol. 194, 751-759. doi: 10.1111/j.1469-8137.2012.04079.x

He, T., Lamont, B. B., and Downes, K. S. (2011). Banksia born to burn. New Phytol. 191, 184-196. doi: 10.1111/j.1469-8137.2011.03663.x

Hoffmann, W. A., Jaconis, S., Mckinley, K. L., Geiger, E. L., Gotsch, S. G., and Franco, A. C. (2012). Fuels or microclimate? Understanding the drivers of fire feedbacks at savanna-forest boundaries. Austral Ecol. 37, 634-643. doi: 10.1111/j.1442-9993.2011.02324.x

Holmes, Z. (2009). Eucalyptus Globulus: Genetic Control of Flammability. BSc (Hons), Hobart, TAS: University of Tasmania.

Jackson, W. D. (1968). Fire, air, earth and water: an elemental ecology of Tasmania. Proc. Ecol. Soc. Aust. 3, 9-16.

Jolly, W. M. (2007). Sensitivity of a surface fire spread model and associated fire behaviour fuel models to changes in live fuel moisture. Int. J. Wildland Fire 16, 503-509. doi: 10.1071/WF06077 
Kane, J. M., Varner, J. M., and Hiers, J. K. (2008). The burning characteristics of southeastern oaks: discriminating fire facilitators from fire impeders. For. Ecol. Manag. 256, 2039-2045. doi: 10.1016/j.foreco.2008.07.039

Keeley, J. E. (2012). Ecology and evolution of pine life histories. Ann. For. Sci. 69, 445-453. doi: 10.1007/s13595-012-0201-8

Keeley, J. E., and Bond, W. J. (1999). Mast flowering and semelparity in bamboos: the bamboo fire cycle hypothesis. Am. Nat. 154, 383-391. doi: 10.1086/303243

Keeley, J. E., Bond, W. J., Bradstock, R. A., Pausas, J. G., and Rundel, P. W. (2011a). Fire in Mediterranean Ecosystems: Ecology, Evolution and Management. Cambridge: Cambridge University Press.

Keeley, J. E., Pausas, J. G., Rundel, P. W., Bond, W. J., and Bradstock, R. A. (2011b). Fire as an evolutionary pressure shaping plant traits. Trends Plant Sci.16, 406-411. doi: 10.1016/j.tplants.2011.04.002

Kerr, B., Schwilk, D. W., Bergman, A., and Feldman, M. W. (1999). Rekindling an old flame: a haploid model for the evolution and impact of flammability in resprouting plants. Evol. Ecol. Res. 1, 807-833.

Keszei, A., Brubaker, C. L., and Foley, W. J. (2008). A molecular perspective on terpene variation in Australian Myrtaceae. Aust. J. Bot. 56, 197-213. doi: 10.1071/BT07146

Koo, E., Pagni, P. J., Weise, D. R., and Woycheese, J. P. (2010). Firebrands and spotting ignition in large-scale fires. Int. J. Wildland Fire 19, 818-843. doi: 10.1071/WF07119

Lamont, B. B., and Lamont, H. C. (2000). Utilizable water in leaves of 8 arid species as derived from pressure-volume curves and chlorophyll fluorescence. Physiol. Plantarum 110, 64-71. doi: 10.1034/j.1399-3054.2000.110109.x

Ledig, F. T., Hom, J. L., and Smouse, P. E. (2013). The evolution of the New Jersey Pine Plains. Am. J. Bot. 100, 778-791. doi: 10.3732/ajb.12 00581

Lindenmayer, D. B., Hobbs, R. J., Likens, G. E., Krebs, C. J., and Banks, S. C. (2011). Newly discovered landscape traps produce regime shifts in wet forests. Proc. Natl. Acad. Sci. U.S.A. 108, 15887-15891. doi: 10.1073/pnas.1110245108

Linder, H. P., and Rudall, P. J. (2005). Evolutionary history of Poales. Ann. Rev. Ecol. Evol. Syst. 36, 107-124. doi: 10.1146/annurev.ecolsys.36.102403.1 35635

Lippincott, C. L. (2000). Effects of Imperata cylindrica (L.) Beauv. (Cogongrass) invasion on fire regime in Florida sandhill (USA). Nat. Areas J. 20, 140-149.

Little, J. K., Prior, L. D., Williamson, G. J., Williams, S. E., and Bowman, D. M. J. S. (2012). Fire weather risk differs across rain forest-savanna boundaries in the humid tropics of north-eastern Australia. Austral Ecol. 37, 915-925. doi: 10.1111/j.1442-9993.2011.02350.x

Loreto, F., Pollastri, S., Fineschi, S., and Velikova, V. (2014). Volatile isoprenoids and their importance for protection against environmental constraints in the Mediterranean area. Environ. Exp. Bot. 103, 99-106. doi: 10.1016/j.envexpbot.2013.09.005

McCaw, W. L., Gould, J. S., Cheney, N. P., Ellis, P. F. M., and Anderson, W. R. (2012). Changes in behaviour of fire in dry eucalypt forest as fuel increases with age. For. Ecol. Manag. 271, 170-181. doi: 10.1016/j.foreco.2012.02.003

McCoy, S., Jaffre, T., Rigault, F., and Ash, J. E. (1999). Fire and succession in the ultramafic maquis of New Caledonia. J. Biogeogr. 26, 579-594. doi: 10.1046/j.1365-2699.1999.00309.x

McGlone, M. S., Perry, G. L. W., Houliston, G. J., and Connor, H. E. (2014). Fire, grazing and the evolution of New Zealand grasses. N. Z. J. Ecol. 38, 1-11.

Midgley, J. J. (2013). Flammability is not selected for, it emerges. Aust. J. Bot. 61, 102-106. doi: 10.1071/BT12289

Mingo, A., and Oesterheld, M. (2009). Retention of dead leaves by grasses as a defense against herbivores. A test on the palatable grass Paspalum dilatatum. Oikos 118, 753-757. doi: 10.1111/j.1600-0706.2008.17293.x

Mitsopoulos, I. D., and Dimitrakopoulos, A. P. (2007). Canopy fuel characteristics and potential crown fire behavior in Aleppo pine (Pinus halepensis Mill.) forests. Ann. For. Sci. 64, 287-299. doi: 10.1051/forest:2007006

Mondal, N., and Sukumar, R. (2014). Characterising weather patterns associated with fire in a seasonally dry tropical forest in southern India. Int. J. Wildland Fire 23, 196-201. doi: 10.1071/WF13002

Moore, B. D., Foley, W. J., Wallis, I. R., Cowling, A., and Handasyde, K. A. (2005). Eucalyptus foliar chemistry explains selective feeding by koalas. Biol. Lett. 1, 64-67. doi: 10.1098/rsbl.2004.0255

Moreira, B., Castellanos, M. C., and Pausas, J. G. (2014). Genetic component of flammability variation in a Mediterranean shrub. Mol. Ecol. 23, 1213-1223. doi: $10.1111 / \mathrm{mec} .12665$
Mount, A. B. (1979). Natural regeneration processes in Tasmanian forests. Search 10, 180-186.

Murphy, B. P., and Bowman, D. J. M. S. (2012). What controls the distribution of tropical forest and savanna? Ecol. Letters 15, 748-758. doi: 10.1111/j.14610248.2012.01771.x

Murray, B. R., Hardstaff, L. K., and Phillips, M. L. (2013). Differences in leaf flammability, leaf traits and flammability-trait relationships between native and exotic plant species of dry sclerophyll forest. PLoS ONE 8:e79205. doi: 10.1371/journal.pone.0079205

Mutch, R. W. (1970). Wildland fires and ecosystems - a hypothesis. Ecology 51, 1046-1051. doi: 10.2307/1933631

Ne'eman, G., Goubitz, S., and Nathan, R. (2004). Reproductive traits of Pinus halepensis in the light of fire - a critical review. Plant Ecol. 171, 69-79. doi: 10.1023/B:VEGE.0000029380.04821.99

Ormeno, E., Cespedes, B., Sanchez, I. A., Velasco-Garcia, A., Moreno, J. M., Fernandez, C., et al. (2009). The relationship between terpenes and flammability of leaf litter. For. Ecol. Manag. 257, 471-482. doi: 10.1016/j.foreco.2008.09.019

Owens, M. K., Lin, C. D., Taylor, C. A., and Whisenant, S. G. (1998). Seasonal patterns of plant flammability and monoterpenoid content in Juniperus ashei. J. Chem. Ecol. 24, 2115-2129. doi: 10.1023/A:1020793811615

Page, W. G., Jenkins, M. J., and Runyon, J. B. (2012). Mountain pine beetle attack alters the chemistry and flammability of lodgepole pine foliage. Can. J. For. Res. 42, 1631-1647. doi: 10.1139/x2012-094

Pausas, J. G., and Moreira, B. (2012). Flammability as a biological concept. New Phytol. 194, 610-613. doi: 10.1111/j.1469-8137.2012.04132.x

Peterson, D. W., and Reich, P. B. (2008). Fire frequency and tree canopy structure influence plant species diversity in a forest-grassland ecotone. Plant Ecol. 194, 5-16. doi: 10.1007/s11258-007-9270-4

Pickup, M., Westoby, M., and Basden, A. (2005). Dry mass costs of deploying leaf area in relation to leaf size. Funct. Ecol. 19, 88-97. doi: 10.1111/j.02698463.2005.00927.x

Ray, D., Nepstad, D., and Moutinho, P. (2005). Micrometeorological and canopy controls of fire susceptibility in a forested Amazon landscape. Ecol. Appl. 15, 1664-1678. doi: 10.1890/05-0404

Ripley, B., Donald, G., Osborne, C. P., Abraham, T., and Martin, T. (2010). Experimental investigation of fire ecology in the C-3 and C-4 subspecies of Alloteropsis semialata. J. Ecol.98, 1196-1203. doi: 10.1111/j.13652745.2010.01700.x

Rollins, M. G., Morgan, P., and Swetnam, T. (2002). Landscape-scale controls over 20th century fire occurrence in two large Rocky Mountain (USA) wilderness areas. Landsc. Ecol. 17, 539-557. doi: 10.1023/A:1021584519109

Rossiter, N. A., Setterfield, S. A., Douglas, M. M., and Hutley, L. B. (2003). Testing the grass-fire cycle: alien grass invasion in the tropical savannas of northern Australia. Divers. Distrib. 9, 169-176. doi: 10.1046/j.1472-4642.2003.00020.x

Rule, S., Brook, B. W., Haberle, S. G., Turney, C. S. M., Kershaw, A. P., and Johnson, C. N. (2012). The aftermath of megafaunal extinction: ecosystem transformation in Pleistocene Australia. Science 335, 1483-1486. doi: 10.1126/science. 1214261

Saha, S., and Howe, H. F. (2001). The bamboo fire cycle hypothesis: a comment. Am. Nat. 158, 659-663. doi: 10.1086/323593

Santana, V. M., Baeza, M. J., and Vallejo, V. R. (2011). Fuel structural traits modulating soil temperatures in different species patches of Mediterranean Basin shrublands. Int. J. Wildland Fire 20, 668-677. doi: 10.1071/WF10083

Saura-Mas, S., Paula, S., Pausas, J. G., and Lloret, F. (2010). Fuel loading and flammability in the Mediterranean Basin woody species with different postfire regenerative strategies. Int. J. Wildland Fire 19, 783-794. doi: 10.1071/WF 09066

Scarff, F. R., Gray, B. F., and Westoby, M. (2012). Exploring phosphate effects on leaf flammability using a physical chemistry model. Int. J. Wildland Fire 21, 1042-1051. doi: 10.1071/WF09065

Scarff, F. R., and Westoby, M. (2006). Leaf litter flammability in some semiarid Australian woodlands. Funct. Ecol. 20, 745-752. doi: 10.1111/j.13652435.2006.01174.x

Schwilk, D. W. (2003). Flammability is a niche construction trait: canopy architecture affects fire intensity. Am. Nat. 162, 725-733. doi: 10.1086/3 79351

Schwilk, D. W., and Ackerly, D. D. (2001). Flammability and serotiny as strategies: correlated evolution in pines. Oikos 94, 326-336. doi: 10.1034/j.1600-0706.2001. 940213.x 
Schwilk, D. W., and Caprio, A. C. (2011). Scaling from leaf traits to fire behaviour: community composition predicts fire severity in a temperate forest. J. Ecol. 99, 970-980. doi: 10.1111/j.1365-2745.2011.01828.x

Schwilk, D. W., and Kerr, B. (2002). Genetic niche-hiking: an alternative explanation for the evolution of flammability. Oikos 99, 431-442. doi: 10.1034/j.16000706.2002.11730.x

Scott, A. C., Bowman, D. M. J. S., Bond, W. J., Pyne, S. J., and Alexander, M. E. (2014). Fire on Earth: an Introduction. Chichester: Wiley Blackwell.

Seo, H., and Choung, Y. (2014). Enhanced vulnerability to fire by Pinus densiflora forests due to tree morphology and stand structure in Korea. J. Plant Biol. 57, 48-54. doi: 10.1007/s12374-013-0359-0

Setterfield, S. A., Rossiter-Rachor, N. A., Hutley, L. B., Douglas, M. M., and Williams, R. J. (2010). Turning up the heat: the impacts of Andropogon gayanus (gamba grass) invasion on fire behaviour in northern Australian savannas. Divers. Distrib. 16, 854-861. doi: 10.1111/j.1472-4642.2010.00688.x

Simon, M. F., Grether, R., De Queiroz, L. P., Skema, C., Pennington, R. T., and Hughes, C. E. (2009). Recent assembly of the Cerrado, a neotropical plant diversity hotspot, by in situ evolution of adaptations to fire. Proc. Natl.Acad. Sci. U.S.A. 106, 20359-20364. doi: 10.1073/pnas.0903410106

Snyder, J. R. (1984). The role of fire. Mutch ado about nothing? Oikos 43, 404-405. doi: $10.2307 / 3544161$

Taylor, C., McCarthy, M. A., and Lindenmayer, D. B. (2014). Nonlinear Effects of Stand Age on Fire Severity. Conserv. Lett. 7, 355-370. doi: 10.1111/conl.12122

Thomas, P. A., and Goodson, P. (1992). Conservation of succulents in desert grasslands managed by fire. Biol. Conserv. 60, 91-100. doi: 10.1016/00063207(92)91159-P

Tng, D. Y. P., Williamson, G. J., Jordan, G. J., and Bowman, D. M. J. S. (2012). Giant eucalypts - globally unique fire-adapted rain-forest trees? New Phytol. 196, 1001-1014. doi: 10.1111/j.1469-8137.2012.04359.x

Trabaud, L. (1976). Flammability and combustibility of main species of garrigues in French Mediterranean region. Ocol. Plant. 11, 117-136.

Trauernicht, C., Murphy, B. P., Portner, T. E., and Bowman, D. M. J. S. (2012). Tree cover-fire interactions promote the persistence of a fire-sensitive conifer in a highly flammable savanna. J. Ecol. 100, 958-968. doi: 10.1111/j.13652745.2012.01970.x

Troumbis, A. Y., and Trabaud, L. (1989). Some questions about flammability in fire ecology. Acta Oecol. Oecol. Plant. 10, 167-175.

Turner, I. M. (1994). A quantitative analysis of leaf form in woody plants from the world's major broadleaved forest types. J. Biogeog. 21, 413-419. doi: $10.2307 / 2845759$
Van Altena, C., Van Logtestijn, R. S. P., Cornwell, W. K., and Cornelissen, J. H. C. (2012). Species composition and fire: non-additive mixture effects on ground fuel flammability. Front. Plant Sci. 3:63. doi: 10.3389/fpls.2012.00063

Veldman, J. W., Mattingly, W. B., and Brudvig, L. A. (2013). Understory plant communities and the functional distinction between savanna trees, forest trees, and pines. Ecology 94, 424-434. doi: 10.1890/12-1019.1

Warman, L., and Moles, A. T. (2009). Alternative stable states in Australia's Wet Tropics: a theoretical framework for the field data and a fieldcase for the theory. Landsc. Ecol. 24, 1-13. doi: 10.1007/s10980-0089285-9

Westoby, M., and Wright, I. J. (2003). The leaf size-twig size spectrum and its relationship to other important spectra of variation among species. Oecologia 135 621-628.

White, C. S. (1994). Monoterpenes - their effects on ecosystem nutrient cycling. J. Chem. Ecol. 20, 1381-1406. doi: 10.1007/BF02059813

Williams, R. J., Wahren, C. H., Bradstock, R. A., and Muller, W. J. (2006). Does alpine grazing reduce blazing? A landscape test of a widelyheld hypothesis. Austral Ecol. 31, 925-936. doi: 10.1111/j.1442-9993.2006. 01655.x

Wittich, K. P. (2011). Phenological observations of grass curing in Germany. Int. J. Biometeorol. 55, 313-318. doi: 10.1007/s00484-010-0338-9

Wyse, S. V., and Burns, B. R. (2011). Do host bark traits influence trunk epiphyte communities? New Zeal. J. Ecol. 35, 296-301.

Conflict of Interest Statement: The authors declare that the research was conducted in the absence of any commercial or financial relationships that could be construed as a potential conflict of interest.

Received: 05 September 2014; paper pending published: 02 October 2014; accepted: 10 October 2014; published online: 04 November 2014.

Citation: Bowman DMJS, French BJ and Prior LD (2014) Have plants evolved to selfimmolate? Front. Plant Sci. 5:590. doi: 10.3389/fpls.2014.00590

This article was submitted to Functional Plant Ecology, a section of the journal Frontiers in Plant Science.

Copyright (C) 2014 Bowman, French and Prior. This is an open-access article distributed under the terms of the Creative Commons Attribution License (CC BY). The use, distribution or reproduction in other forums is permitted, provided the original author(s) or licensor are credited and that the original publication in this journal is cited, in accordance with accepted academic practice. No use, distribution or reproduction is permitted which does not comply with these terms. 